UDC 371.13
DOI https://doi.org/10.24919/2308-4863/37-3-43

Vira CHORNOUS, orcid.org/0000-0003-3756-1269

Candidate of Pedagogical Sciences, Associate Professor at Social Sciences and Humanities Department Municipal Institution of Higher Education "Rivne Medical Academy" of Rivne Region Council (Rivne, Ukraine)0672528939@ukr.net

\title{
CREATIVITY OF THE FUTURE TEACHER OF A FOREIGN LANGUAGE AS A BASIS OF PROFESSIONAL FORMATION
}

The article analyzes the specifics of training a future creative teacher of a foreign language in the information society. It is noted that the development of the creative personality of the teacher is an important task of higher education institutions, because it depends on the development of the creative personality of students, whose creative growth is carried out in interaction with the creative development of the teacher. The actuality of this problem at the present stage of development of society is revealed, the essence of such concepts as personality, creativity, creative activity of personality is determined, the views of psychologists and educators on the concept are analyzed.

It is emphasized that despite the significant number of publications devoted to the study of the content of the concept of "creativity», in the scientific and pedagogical literature there are different approaches to its interpretation. The uderstanding of the essence of pedagogical creativity by domestic and foreign scientists is revealed. It has been found that modern pedagogical science treats this concept as a meaningful category. Scientists consider the creativity of a teacher as a specific activity that has a certain structure: motives, purpose, content, subject, object, means, conditions of realization, approaches, results.

The main tasks of the process of formation of creative activity of students - future foreign language teachers are outlined, pedagogical conditions are considered as a complex of necessary means that contribute the success of formation of creative independence of a student of pedagogical university. As a result of the research it was found that the pedagogical conditions of forming creative independence of pedagogical university students are as follows: creation of pedagogical, comfortable and educational environment, reflective self organization of creative independence, involvement of students in «improvisational» field of activity and creative design activity. Attention is paid to the development of creative iniative, creative thinking, creative position and the formation of individual style of activity of the future English teacher.

Key words: creativity, creative activity, pedagogical creativity, future English teacher, professional activity.

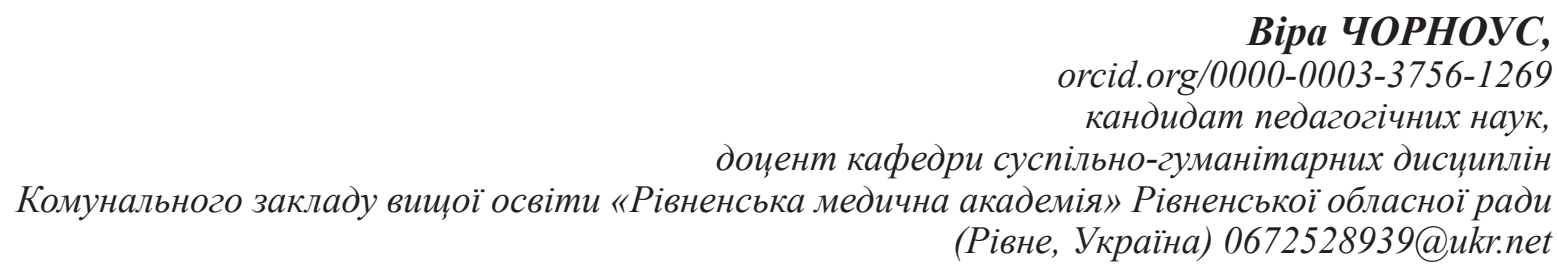

\section{ТВОРЧІСТЬ МАЙБУТНЬОГО ВЧИТЕЛЯ ІНОЗЕМНОЇ МОВИ ЯК ОСНОВА ПРОФЕСІЙНОГО СТАНОВЛЕННЯ}

У статті проаналізовано особливості підготовки майбутнього творчого вчителя іноземної мови в умовах інформаційного суспільства. Зазначено, щзо розвиток творчої особистості педагога є важливим завданням закладів вищої освіти, тому щз саме від иьього залежить розвиток творчої особистості студентів, творче зростання яких здійснюється у взаємодї з творчим розвитком учителя. Розкрито актуальність зазначеної проблеми на сучасному етапі розвитку суспільства, визначено сутність таких понять, як «особистість», «творчість», «творча активність особистості», проаналізовано погляди психологів і педагогів щзодо означуваного поняття.

Підкреслено, щзо, незважаючи на значну кількість публікацій, присвячених вивченню змісту поняття «творчість», у науково-педагогічній літературі спостерігається неоднозначність підходів до його трактування. Розкрито розуміння сутності поняття «педагогічна творчість» вітчизняними та зарубіжними науковцями. 3'ясовано, щуо сучасна педагогічна наука трактує ще поняття як багатозначну категорію. Учені розглядають творчість учителя як специифічну діяльність, щчо має певну структуру: мотиви, мету, зміст, суб'єкт, об'єкт, засоби, умови здійснення, підходи, результат.

Окреслено основні завдання процесу формування творчої активності студентів - майбутніх учителів іноземної мови, розглянуто педагогічні умови як сукупність необхідних заходів, щуо сприяють успішності формування творчої самостійності студента педагогічного університету. Виявлено, щзо комплексом педагогічних умов 
формування творчої самостійності студентів педагогічного університету є такі умови: створення педагогічно комфортного освітнього середовища, рефлексивна самоорганізачія творчої самостійності, залучення студентів до «імпровізачійного» поля діяльності та до творчої проєктувальної діяльності Звертається увага на розвиток творчої ініціативи, творче мислення, творчу позицію та формування індивідуального стилю діяльності майбутнього вчителя англійської мови.

Ключові слова: творчість, творча активність, педагогічна творчість, майбутній учитель англійської мови, професійна діяльність.

Formulation of the problem. The intensive sociological and economic changes taking place in modern society make completely new requirements on the development of the teacher's personality, that is: the ability to orientate in new, uncertain situations, the ability to make decisions and determine immediate and long terms goals, to be socially active, creative and successful. This process is accompanied by significant changes in pedagogical theory and practice of educational activity in higher education institutions. Due to this, the tasks of creating psychological and pedagogical conditions for the development of the creative personality of the teacher, his creative potential and so on asquire special significance.

The profession of a teacher is one of the responsible ones, because he creates the future of the country, because the variety of the development of knowledge of the young generation depends on his activity. Modern society needs not just a subject teacher, but a specialist with a wide range of vital and professional competencies formed at a high level. It should be noted that the specificity of a foreign language as a subject is a number of differences from the native language, among which are the following: the way of mastering a foreign language (learning a foreign language begins with awareness, while learning the native ones begins not consciously, not purposefully), a foreign language is used in communicative and a native language is used in subject communicative activity etc. Therefore, learning a foreign language requires a special approach, special pedagogical training.

Modern conditions for reforming the higher education system require new research from many didactic problem, namely: determining the nature, content, structure and conditions for the development of pedagogical creativity. Unresolved in the didactics of these problems creates certain difficulties in the development of pedagogical creativity in future foreign language teachers. However, despite this level of research of the problem of the creative development of future teachers, the issue of studying the pedagogical creativity of foreign language teachers as a feature of professional training of future foreign language teachers is underdeveloped and needs further study due to its practical application in teaching.

Thus, the study of pedagogical creativity as a feature of professional training of future foreign lan- guage teachers in higher education institutions is relevant.

Research analysis. The concept of "creativity» has been studied by various philosophers, psychologists and educators. Scientists consider creativity as an activity, the result of which is the creation of new qualitative mateial and spiritual values. At the same time creativity is a person's ability to create a new reality from the existing available material on the basis of knowledge of the laws of the objective world, which satisfies various social and personal needs.

At the present stage of development of science and education issues in the field of creative personality is the most important area of scientific and theoretical research. At the present, research on the definition of psychological aspects and features of creative activity has been deeply designed (J. Gilford, O. Kulchytska, V. Molyako, K. Rogers, B. Teplov, E, Torrens, V. Frankl, V. Shadrikov, ets.); problems of creative abilities and possibilities of preparation of creativity of the person are studied (I. Bila, D. Bohoyavlenska, E. De Bono, V. Druzhinin, O. Zavhorodnya, N. Leites, O. Matyushkin, L. Naidenova, Ya. Ponomarrev, J. Renzulli, A, Taylor, L. Thurston, E. Torrens, T. Tretyak etc.).

The problem of creativity in the professional training of foreign language teachers is given attention in the research of I. Hrynenko (formation of creative thinking of the future foreign language teacher), L. Sachenko (creative approach in making lesson plans), T. Zubenko (ways to improve the training of foreign language teachers classes), N. Solovyova (methodical creativity in practical classes on methods of teaching a foreign language) and others.

In the basis of the modern understanding of pedagogical creativity as the fundamental part of professional training are scientific and theoretical ideas of O. Antonova, N. Berezanska, Y. Zinkovsky, V. Kan-Kalik, M. Leshchenko, T. Lubart, V. Nurkov, S. Sysoeva, R. Sternberg, L. Khomich and others.

Nowadays, there is a tendency to change the oranization of the educational process and its content at school, so the problem of developing a creative iniative of teachers to find and use non traditional forms and methods of work, related to the acquirement of knowledge needed to students and the prevalence of professional oriented information system is relevant. 
However the process of training a foreign language teacher has yet become the subject of a comprehensive study, the object of a systematic approach to it as a integral phenomen. That is why there is a need to revise the content, forms and methods of work in the pedagogical process to the development of a teacher who would have a subject of a speciality and methods of its teaching and be able to realize certain tasks creatively.

Thus, the issue of creativity is relevant as a feature of professional training of future foreign language teachers in higher education institutions. Therefore, this problem remains important and requires deep and comprehensive research.

The purpose of the article is to substantiate theoretically the specifics of pedagogical creativity of the future foreign language teacher as the basis of his professional development.

The main material. Reconstruction of the education system, orientation on a new type of pedagogical worldview require future foreign language teachers to be able to think creatively and at any moment to activate the potential, to act creatively and productively. A particular importance in the field of higher education is the problem of training a new type of teacher, a professional teacher capable for creativity, rapid and high quality solution of solving pedagogical problems. Today's young specialists with the higher education must be prepared to solve professional problems that require non standard creative solutions and are capable for creative self development.

Variety of pedagogical situations, taking into account the teacher's age characteristics of students (predominance of game interest, voluntary behavior, visual thinking, etc.), the need for the lesson dynamics, integration of different activities, the need to use game technologies in teaching English requires creative approaches to analysis and problems solving in the learning process of educational institution, those that generate something new, previously unknown on the basis of understanding gained experience and the formation of new combination of knowledge, skills, abilities.

Therefore, one of the main tasks of higher education is a creation an educational and training environment that will promote the development of creative thinking of future teachers who are able to make non standard and, most importantly, effective decisions in the rapid information and technological development of society. According to T. Sidorenko, the characteristics of a creative teacher are determined by the ability to notice and formulate alternatives, to question the obvious, the ability to get to the essence of the problem, to see the result of its solution (Sydorenko, 2001: 55-56).
In the process of reforming education, the formation of creative skills of future teachers becomes determinative. Considering the problem of persoal creativity in the process of professional development, N. Berezanska and V. Nurkov along with different skills and personal characteristics singled out the creativity. They noted that this phenomen is a factor that provides: the creation of new intellectual products related to a new professional field of knowledge and the solution of non standard tasks based on them; construction of original approaches to understanding and interpretation of knowledge; use of professional skills in different situations; creating conditions for self development of knowledge, which increases the level of their universality (Berezanska, 2002).

Creativity of a foreign language teacher is characterized by the existence of contradictions in a problem situation or creative task, the presence of objective (social, material) and subjective (goals, knowledge, skills, motivation, etc.), prerequisites for creativity in learning a foreign language novelty and originality on the process and outcome of training (Sydorenko, 2001: 55). However, creativity depends on a number of certain factors, in particular, the potential of the individual, social and professional experience, psychological, pedagogical and subject knowledge, the creation of new ideas, skills and abilities of the future specialist. Pedagogical creativity is appeared in the process of work, the desire to improve the professional level and skill.

The study of pedagogical creativity and the peculiarities of preparation of future teachers for it is given due to attention in the researches of V. Kan-Kalik, M. Leshchenko, N. Kichuk, S. Sysoeva, L. Chomuch and others. Thus, the scientist S. Sysoeva identifies the following signs of pedagogical creativity:

- high level of social and moral consciousness;

- search and transforming style of thinking;

- developed intellectual and logical abilities (ability to analyze, justify, explain, highlight etc.);

- problem vision, creative fantasy, developed imagination;

- spesific personal qualities (love for children, selflessness, courage, willingness to take resonable risks in professional activity, purposefulness, curiosity, independence, perseverance, enthusiasm);

- specific mitives (the need to realize their «me», the desire to be recognized, creative interest, enthusiasm for the creative process and their own activities, the desire to achieve greater efficiency);

- communicative skills, ability to self government, high level of general culture (Sysoeva, 1998).

In the process of training the future teacher creative position is formed. O. Kutsevol defines the crea- 
tive position as a mobile conscious and motivational readiness of the subject to creative transformations, actions in various situations. Accordingly, it shows itself in the following qualities of the future teacher:

- attitude to creativity as a value of human existence;

- the need for creative activity, creative attitude to yourself and world;

- readiness for choice and transformation in pedagogical activity;

- desire for high results and creative achievements;

- awareness of teaching as a vocation (Kutsevol, 2007: 25).

The development of individual creative style of a future foreign language teacher depends on student's personality, his individual characteristics, level of professional training, creative search in certain field of knowledge. In this regard, it is appropriate to talk about the pedagogical features of the training of future foreign language teachers, among which are the following:

- pedagogical activity of the teacher should be directed on perfomance of educational, developmental, scientific, organizational functions;

- professional development of personality is based on the principle of creative organization of education, conformity of individual qualities of personality to features of pedagogical activity.

According to R. Skulsky, pedagogical creativity is a qualitative characteristic of a teacher's professional activity, the formation and development of creative abilities of future teachers and their preparation for creative activity should be considered as a restructing of the educational process to create conditions for identifying and developing creative abilities of each individual. The process of formation and development of the teacher's creative personality becomes more successful when the student realizes himself in the role of a teacher (Skulsky, 1992: 62-65).

Creativity is related to the problem of creative thinking, which was studied by L. Vygotsky, S. Sysoeva, A. Osborn, G. Wallase and others. L. Zasekina defines creative thinking as a process that is developed in certain time with qualitatively expressed stages and requires special knowledge and skills to solve creative tasks, certain personal qualities, as well as, the ability to think systemically, it is characterized by originality, creative imagination (Zasekina, 2000: 30-31). In addition, the following features of creative thinking are distinguished: fluidity, flexibility, originality, detailed development, visualization, transformation, intuition, synthesis. Creative thinking needs to be formed throughout a person's life, starting from early childhood. Therefore, higher education institutions should have a creative atmosphere conductive to the formation of the induviduality of future teachers, creative thinking.

Pedagogical conditions that contribute to the formation of creative thinking of future foreign language teachers:

1. Making a creative friendly atmosphere involves the principle of optimal communication between teachers and students, it is the only criterion and psychological key in building pedagogical communication between participants in the educational process. The organization of an individual situation of success is such a purposeful, organized combination of conditions under which it is possible to achieve significant results in the activities of both the individual and the team as a whole (Belkin, 2013).

2. Reflexive self organization of creative independence involves the development of intellectual mobility, reflection of the student's pedagogical experience and emotional capabilities. Students'own personal position to improve their creative growth, attitude to the analysis and understanding of the process and result of their activities, understanding of their induviduality, dignity lead to conscious and purposeful management of their activities.

3. Involment of students in the «improvisational field of activity». An improvisation is a basis of independent creative activity, the starting mechanism in the complex process of activating the creative potential of students, the education of interest in pedagogical activities. Pedagogical improvisation (techniques and methods) determines the positive reaction of students to the subject, stimulates the development of the emotional sphere of personality, emotional sensitivity of future teaching, promotes the principle of creative transfering of existing knowledge, skills and abilities of developing personality, determines purposeful inclusion in the creative process, designing improvisational creative tasks which will become the basis for developing a creative project (Hrynenko, 2003: 155).

4. Involvement of students in creative design activities aimed at mastering the program material through the creation of a creative project, its design and public defense.

Thus, the interest of the future specialist in learning a foreign language largely depends on the teacher, his pedagogical and methodological skills, artistry and creativity, taking into account the psychological characteristics of students, their needs and interests. Nowadays, in the conditions of information society, when education is being reformed, the formation of 
creative skills of the future teacher in professional training becomes important. It is through the creativity that teachers can solve problems that arise in education, take a new approach to traditional work, be interested in learning, that is develop an individual, creative style of work.

Conclusions. Thus, the development of creative qualitues of future teacher of foreign language in high school should include:

- awareness of future teachers of personal and professional opportunities, development of pedagogical abilities to the creative level;

- enjoyment and need for novelty and non standard ways of solving professional problems;
- attitude to creativity and overcoming stereotypical ways and formalism in professional actions, forecasting ways and improving the creative potential of future specialist.

Further study, in our opinion, requires the problems of methods of diagnosing pedagogical creativity, the use of certain pedagogical forms and teaching methods aimed at developing creative thinking of future foreign language teachers, ways to improve training, as well as the practical aspect of future foreign language teacher training, improvement the level of teaching disciplines, developments of methods that will help to make a foreign language lesson productive, dynamic and interesting.

\section{BIBLIOGRAPHY}

1. Белкин А. Ситуация успеха : книга для учителей. Екатеринбург, 2013. С. 17-22.

2. Гриненко I. Педагогічні умови формування творчого мислення майбутнього вчителя іноземної мови: теоретико-методичний аспект. Наукові записки. Педагогіка. 2003. № 3. С. 149-155.

3. Засєкіна Л. Особливості формування професійно-творчого мислення майбутнього фахівця іноземної мови : дис. ... канд. психол. наук : 19.00.07 ; Волинський держ. ун-т ім. Лесі Українки. Луцьк, 2000. 206 с.

4. Куцевол О. Портрет творчого вчителя літератури. Дивослово. 2007. № 1. С. 24-29.

5. Розробка системи психологічного обстеження і моніторингу універсальних умінь в цілях атестації і підбору персоналу / Н. Березанська та ін. Розвиток особистості. 2002. № 2. С. 136-155.

6. Сидоренко Т. Творчість у діяльності вчителя. Рідна школа. 2001. № 5. С. 55-57.

7. Сисоєва С. Педагогічна творчість учителя: визначення, теоретична модель, функції підготовки. Педагогіка $i$ психологія. 1998. № 2. С. 79-82.

8. Скульський Р. Підготовка майбутніх учителів до педагогічної творчості : монографія. Київ : Вища школа, 1992. $135 \mathrm{c}$.

9. Donahue M. Nursing: the finest art, an illustrated history. St Louis : CV Mosby, 2010. 390 p.

10. Tardif T., Sternberg R. What we know about creativity? The nature of creativity, 1988. P. 429-446.

11. Torrance E. The nature of creativity as manifest in its testing. 1988. P. 43-75.

\section{REFERENCES}

1. Belkyn A. Sytuatsyia uspekha [Sittuation of success] : kn. dlia uchytelei. Ekaterynburh, 2013. P. 17-22 [in Russian].

2. Hrynenko I. Pedahohichni umovy formuvannia tvorchoho myslennia maibutnoho vchytelia inozemnoi movy: teoretykometodychnyi aspekt [Pedagogical conditions of formation of creative thinking of the future teacher of a foreign language: theoretical and methodological aspect]. Pedahohika: Naukovi zapysky. Ternopilskyi derzh. ped. un-t. Ternopil, 2003. № 3. P. 149- 155 [in Ukrainian].

3. Zasiekina L. Osoblyvosti formuvannia profesiino-tvorchoho myslennia maibutnoho fakhivtsia inozemnoi movy [Features of formation of professional and creative thing of future specialist of a foreign language].: dys. ... kand. psykhol. nauk : 19.00.07 / Volynskyi derzh. un-t im. Lesi Ukrainky. Lutsk, 2000. 206 p. [in Ukrainian].

4. Kutsevol O. Portret tvorchoho vchytelia literatury [ Portrait of a creative literature teacher]. Dyvoslovo. 2007. № 1. P. 24-29 [in Ukrainian].

5. Rozrobka systemy psykholohichnoho obstezhennia i monitorynhu universalnykh umin $\mathrm{v}$ tsiliakh atestatsii i pidboru personalu [Development of a system of psychological examination and monitoring of universal skills for the purpose of certification and selection of personnel] / N. Berezanska ta in. Rozvytok osobystosti. 2002. № 2. P. 136-155 [in Ukrainian].

6. Sydorenko T. Tvorchist u diialnosti vchytelia [Creativity in teacher’s activity]. Ridna shkola. 2001. № 5. P. 55-57 [in Ukrainian].

7. Sysoieva S. Pedahohichna tvorchist uchytelia: vyznachennia, teoretychna model, funktsii pidhotovky. Pedahohika i psykholohiia [Pedagogical creativity of a teacher: definition, theoretical model, training fuctions. Pedagogy and psychology]. 1998. № 2. P. 79-82 [in Ukrainian].

8. Skulskyi R. Pidhotovka maibutnikh uchyteliv do pedahohichnoi tvorchosti: Monohrafiia [Preparation of future teachers to pedagogical creativity]. Kyiv: Vyshcha shkola, 1992. 135 p. [in Ukrainian].

9. Donahue M. Nursing: the finest art, an illustrated history. St Louis: CV Mosby, 2010. 390 p.

10. Tardif T., Sternberg R. What we know about creativity? The nature of creativity, 1988. P. 429-446.

11. Torrance E. The nature of creativity as manifest in its testing. 1988. P. 43-75. 